\title{
DISKURSUS MANAJEMEN BENCANA ERA COVID-19
}

\author{
Burhanudin Mukhamad Faturahman ${ }^{1}$ \\ ${ }^{1}$ Pusat Penelitian Sekretariat Jenderal DPR RI \\ e-mail : burhanmfatur@gmail.com
}

\begin{abstract}
Disaster management is a series of disaster cycles including pre-disaster, emergency, and post-disaster response stages with different handling characteristics at each stage. Based on these stages, the covid-19 disaster event has special characteristics where the non-natural disaster has a disaster emergency status as well as a recovery stage. The occurrence of two stages of a disaster at once in one disaster event causes obscurity and poor policy coordination in the emergency response period. The lack of the role of BNPB and BPBD during the disaster emergency caused policies to become conflicted between the health sector and the economic sector. Therefore, it is necessary to revise the disaster management law by strengthening the role of bnpb coordination as the main actor in mobilizing strategic resources both technical and non-technical. The revision of the disaster management law may refer to local government laws to harmonize disaster emergency policies at the central and regional levels. In addition, collaboration with academics is important to provide health resources for handling covid-19 in the country in the production, distribution, and consumption process.
\end{abstract}

Keywords: Disaster management; covid-19; emergency response. 


\section{Pendahuluan}

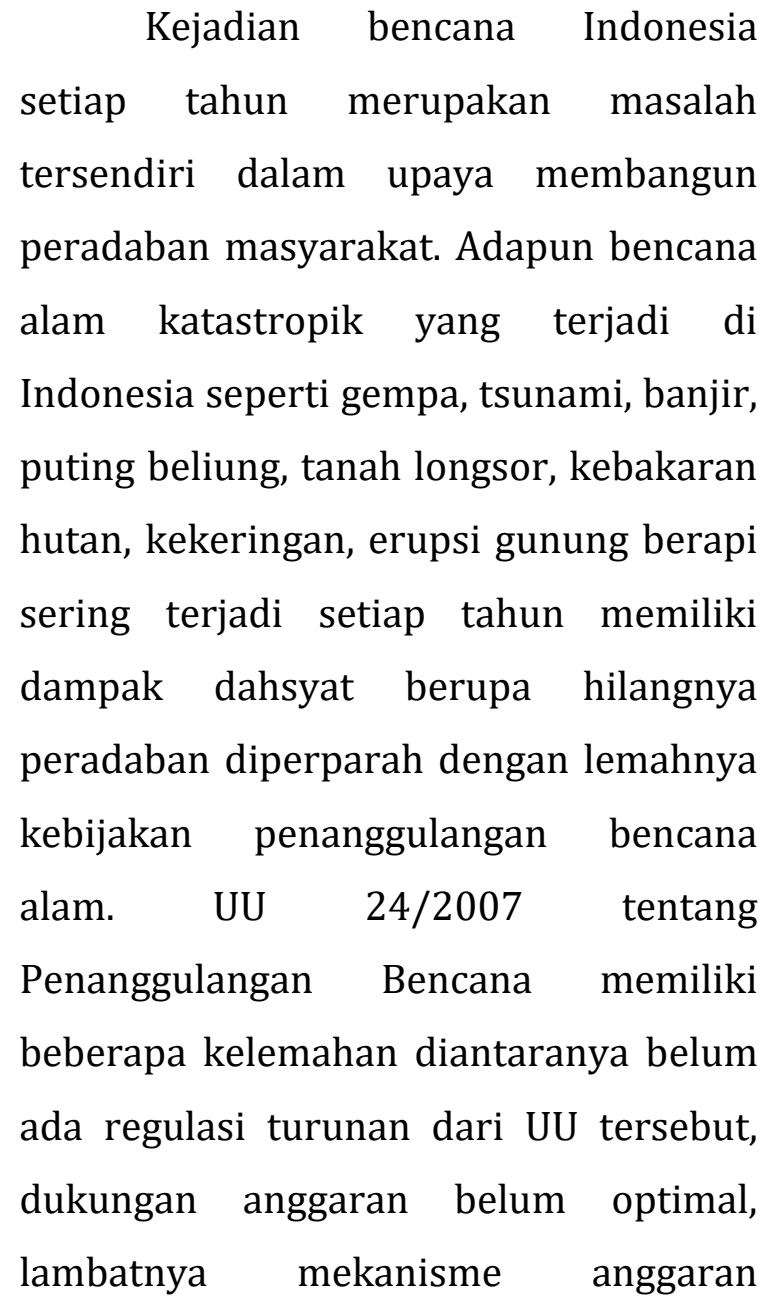

penanggulangan bencana, upaya mitigasi dan tanggap darurat serta koordinasi pemerintah pusat dan daerah masih lambat (Carolina,2018).

Menurut data BNPB di tahun 2020 telah terjadi 2.925 kejadian bencana alam dengan rincian bencana hidrometeorologi sebanyak 1.065 kejadian, angin puting beliung sebanyak 873 dan tanah longsor 572 kejadian. Selanjutnya karhutla telah terjadi sebanyak 326, gelombang pasang dan abrasi 36 kejadian dan kekeringan terjadi sebanyak 29 kejadian samentara bencana gempa bumi telah terjadi sebanyak 16 kali dan erupsi gunung berapi sebanyak 7 kejadian (BNPB,2020). Berikut disajikan gambar kejadian bencana sepanjag tahun 2020 .

Gambar 1. Jumlah Kejadian Bencana Alam di Indonesia tahun 2020

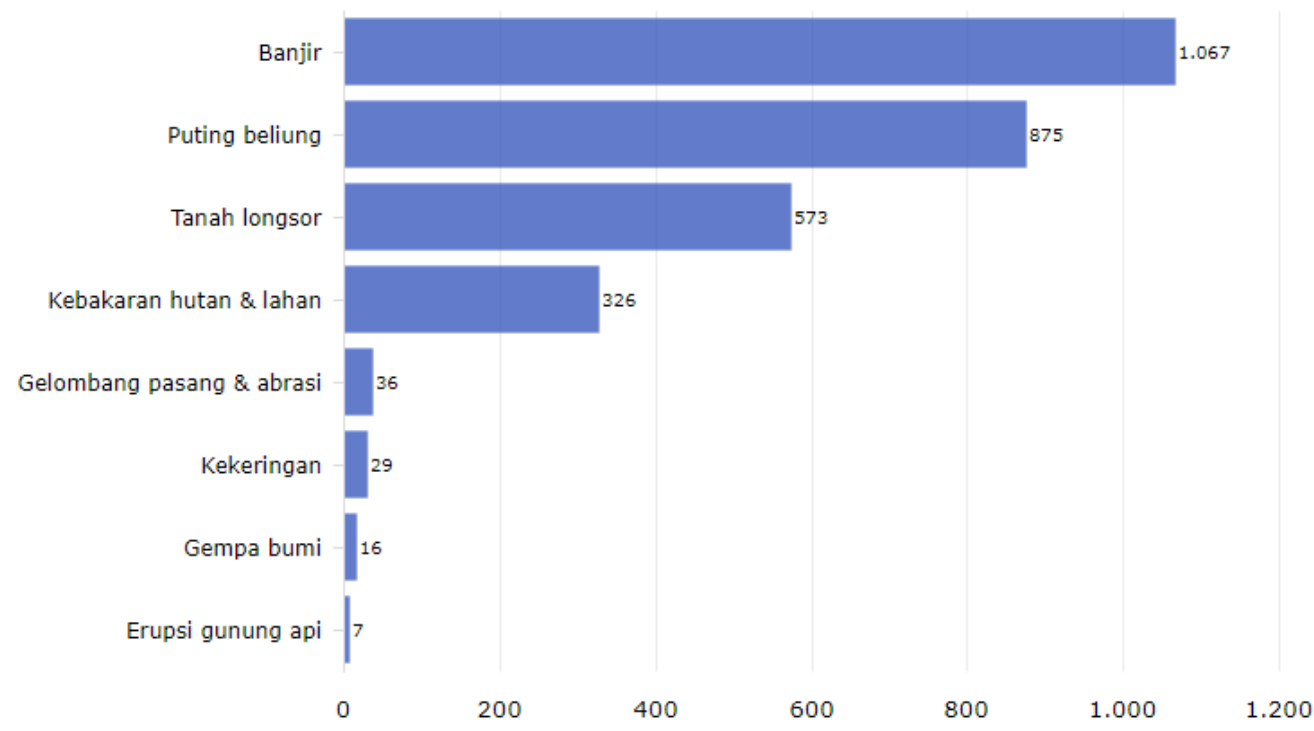

Sumber: Badan Nasional Penanggulangan Bencana (BNPB) per 29 Desemeber 2020 
Kondisi empiris kejadian bencana alam tahun 2020 memiliki frekuensi lebih rendah dibandingkan kejadian bencana tahun 2019 sebanyak 3.814. Namun fluktuasi kejadian bencana (penurunan jumlah kejadian) tidak dapat dijadikan patokan bahwa suatu daerah terbebas dari ancaman bencana alam. Mengingat sebagian besar (80 persen) penduduk Indonesia hidup di daerah rawan bencana serta trend bencana alam selama lima tahun terakhir terjadi karena kerusakan lingkungan hidup menjadikan tingkat kerawanan dan kerentanan semakin meningkat (Putera, Valentina \& Rosa, 2020). Ancaman bencana alam turut memperburuk ekonomi Indonesia dimana pada tahun 2009 hingga 2018 total kerusakan ekonomi mencapai 10 miliar U\$ dollar. Dikawasan ASEAN Indonesia memiliki resiko besar terhadap ancaman bencana alam bersama Filipina dan Thailand dengan total kerusakan ekonomi masingmasing sebesar 19 miliar U\$ dollar dan 46 miliar U\$ dollar di tahun yang sama (Ikeda \& Palakhamarn ,2020). Besarnya dampak kerugian dan kerusakan dari bencana alam memberikan pola pikir pentingnya penanggulangan bencana sebelum bencana itu terjadi atau lebih sering disebut pengurangan resiko bencana (PRB).
Dalam setahun terakhir berbagai negara di dunia dilanda bencana nonalam yaitu Covid-19 termasuk Indonesia. Pandemi tersebut dalam skala nasional memerikan dampak kerusakan ekonomi yang cukup signifikan dimana Pendapatan bruto nasional hanya mencapai 0.5 persen. Tidak hanya itu, bertambahnya angka pengangguran sebanyak 1,73 juta orang di tahun 2020 dikarenakan pemutusan hubungan kerja berdampak kepada pengangguran, mencari pekerjaan sulit hingga bertambahnya masyarakat miskin. Tak dapat dipungkiri bahwa kejadian bencana selalu memberikan dampak serius bagi perekonomian negara termasuk bencana pandemi (Sumarni,2020).

Disamping periode berakhirnya pandemi yang belum bisa diprediksi masih terdapat sejumlah persoalan yaitu total 514 Kabupaten dan Kota, 96 persen berkategori sangat berisiko kebakaran hutan, 77 persen sangat berisiko kekeringan, 67 persen sangat berisiko gempa bumi, 66 persen sangat berisiko cuaca ekstrem, 63 persen sangat berisiko banjair, 59 persen sangat berisiko abrasi dan gelombang ekstrem, 55 persen sangat berisiko tanah longsor, 34 persen sangat berisiko terdampak tsunami serta 9 persen sangat berisiko terdampak 
erupsi gunung berapi (Dzakwan,2020).

Belum tuntasnya pandemi Covid-19 menjadikan ancaman serius bagi kesehatan masyarakat mendorong terjadinya resesi ekonomi akibat mandegnya proses produksi dan turunnya konsumsi. Bencana masa kini menjadikan dilema tentang apa yang harus diutamakan antara mengutamakan kesehatan atau menjaga aktifitas ekonomi tetap berjalan.

Fenomena multi-bencana ini semakin memberikan justfikasi bahwa aspek kebencanaan dalam membangun peradaban masyarakat sangatlah penting. Di beberapa daerah terdapat resiko bencana yang relatif sedikit namun dampak yang ditimbulkan akan sangat destruktif. Kejadian bencana yang sifatnya tidak dapat diprediksi terlebih akhir pandemi covid-19 masih belum bisa diprediksi menjadi tantangan pengelolaan bencana berbagai stakeholder. Persoalan lainnya terdapat pada komitmen politik lokal terhadap kesiapsiagaan bencana alam dalam situasi normal masih sangat rendah (Vermonte \& Dzakwan, 2020). Berdasarkan uraian permasalahan di atas rumusan masalah dari penulisan ini yaitu bagaimana posisi tahap manajemen bencana di masa pandemi covid-19 dan bagaimana kebijakan manajemen bencana pemerintah di masa pandemi. Sedangkan tujuan dari penulisan ini yaitu mendeskripsikan dan menganalisis posisi tahapan manajemen bencana di masa pandemi covid-19 dan kebijakan manajemen bencana pemerintah di masa pandemi.

\section{Landasan Teori Manajemen Bencana}

Definisi bencana dapat diketahui dari berbagai persepsi karena kompleksitas kejadiannya. Menurut Singh, bencana adalah kosekuensi bencana alam (erupsi vulkanik, gempa bumi dan tanah longsor) yang merubah tahap potensial ke tahap aktif dan sebagai hasil dari dampak aktifitas manusia. Pendapat lainnya dari McEntire yaitu bencana merupakan efek negatif antara interaksi agen/aktor utama, lingkungan alam, aktivitas manusia atau kombinasi keduanya dengan kerentanan. Sementara definisi dari UNDP tentang bencana adalah kombinasi bahaya dari tindakan manusia atau fenomena alam dengan kondisi kerentanan. Unsur bencana alam dari ketiga pendapat tersebut menitikberatkan bahwa kejadian bencana alam tidaklah berdiri sendiri melainkan terdapat kaitan antara perilaku manusia, kondisi kerentanan sehingga fase potensial berubah ke fase aktif (Samekto \& Nuh,2017). 
Kombinasi beberapa aspek dalam bencana dapat memberikan dampak sangat merusak pada populasi yang rentan, menimbulkan korban dan gangguan. Lebih lanjut Khan, Vasilescu \& Khan (2008) membagi komponen utama bencana menjadi: 1) kejadian/ bahaya (Hazard). Bahaya adalah kondisi dari perilaku manusia dan kejadian alam yang mengancam atau berpotensi menyebabkan cidera, kerusakan pada barang atau lingkungan. 2) kerentanan yaitu tingkat komunitas, struktur, layanan atau area geografis yang rusak atau terganggu oleh kejadian bencana tertentu berdasarkan kondisi indigenous alam dan kedekatan dengan daerah rawan bencana. a) kerentanan fisik yaitu mencakup siapa dan apa yang memungkinkan dirusak oleh bencana alam mencakup manusia, infrastruktur, kedekatan dengan sumber bencana. dan lain-lain. b) kerentanan sosial-ekonomi yaitu derajat populasi yang terpengaruh bencana secara fisik dan ekonomi yang ditentukan oleh intensitas dampaknya. 3) kapasitas adalah sumberdaya dan kekuatan yang dimiliki untuk kesiapan, pencegahan, mitigasi dan rehabilitasi dengan cepat. 4) resiko adalah pengukuran dari kerusakan atau kehilangan saat kejadian bencana pada area dan waktu yang spresifik.

Manajemen bencana memiliki kaitan yang kuat setiap tahapannya. Warfield (2008) menyebutkan bahwa manajemen bencana bertujuan mengurangi resiko atau menghindari potensi kehilangan dari bencana, ketepatan dan kecepatan pertolongan untuk meminimalisir korban. Siklus dalam manajemen bencana tersebut merupakan proses kegiatan pemerintah, swasta dan masyarakat untuk mengurangi dampak bencana, reaksi saat bencana dan langkah pemulihan setelah bencana. ketepatan tindakan pada setiap poin tersebut dapat mengarahkan kesiapsiagaan yang lebih luas, peringatan dini lebih baik, mengurangi kerentanan atau pencegahan pada tahap siklus selanjutnya. Adapun siklus dalam menajemen bencana sebagai berikut: 
Gambar 2. Siklus manajemen bencana

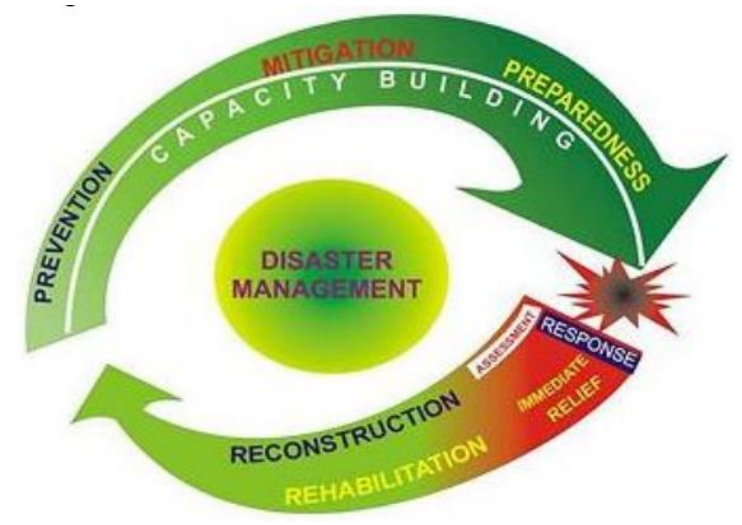

Sumber: Burdak (2018)

Upaya mitigasi bertujuan menghindari bahaya atau mengurangi dampak dari kejadian bencana dari perkembangan awal hingga terjadinya bencana secara keseluruhan baik secara struktural dan non struktural (Faturahman, 2018a). Fase ini ini termasuk pengukuran pencegahan atau pengurangan dampak bencana yang berfokus jangka panjang dimana pada fase ini jelas berbeda dengan fase lainnya. aktor yang terlbat dalam fase ini yaitu level personal, level komunitas, lembaga-lembaga masyarakat, pemerintah dan berbagai aktor lainnya. Pada level personal diutamakan pengetahuan tentang resiko kehilangan, kesehatan keluarga dan properti. Fase kesiapsiagaan adalah perencanaan untuk bertindak meliputi latihan, sistem peringatan dini, edukasi yang tidak bisa dipisahkan dari mitigasi. Perbedaan mitigasi dengan kesiapsiagaan terdapat pada periode waktu dimana mitigasi bersifat jangka panjang sedangkan kesiapsiagaan bersifat jangka pendek (Adalbahi,2014). Kesiapsiagaan secara umum dapat diukur melalui:

1. Komunikasi dengan memperhatikan rantai komando

2. Praktik dan pengembangan koordinasi multi-agen dan komando saat insinden.

3. Mempersiapkan layanan perawatan dan pelatihan dari tahap tanggap darurat

4. Pengembangan dan pelatihan metode peringatan populasi darurat dengan tenda darurat dan rencana pencabutan

5. Penyimpangan, perekaman dan perawatan suplai dan peralatan bencana

Fase tanggap darurat merupakan upaya mengurangi bahaya dari bencana meliputi penyelamatan dan pencarian, peta darurat yang dilakukan segera 
setalah terjadi bencana ketika tidak dalam keadaan normal. Fase terakhit yaitu pemulihan atau recovery adalah mengembalikan komunitas pada keadaan normal kembali. Recovery terbagi menjadi tindakan rehabilitasi dan rekonstruksi pada jangka menengah dan jangka panjang dari sebuah bencana. Adalbahi, et al (2014) berpendapat bahwa idealnya tahap paling pertama pada siklus bencana adalah mitigasi yang didorong sebelum kejadian bencana, namun sebagian besar kota terlebih dahulu melalui beberapa tahap bencana sebelum melakukan mitigasi bencana dengan baik.

\section{Metode Penelitian}

Tulisan ini membahas pengelolaan bencana covid-19 dari perspektif manajemen bencana dengan metode deskriptif. Jenis penelitian deskriptif bertujuan memperoleh pehaman secara komprehensif dari suatu fenomena atau kejadian. Hasil deskripsi ini melalui proses review literatur yang berkaitan dengan penanganan bencana covid-19 kemudian dikaitkan dengan siklus manajemen bencana untuk memperoleh penjelasan dan analisis rinci dari kejadian bencana dan upaya solutif penanganan bencana covid-19.

\section{Hasil dan Pembahasan}

Bias manajemen bencana Covid-19
Kejadian bencana non-alam (pandemi) covid-19 menjadi hal yang baru dalam konteks penanggulangan bencana di Indonesia. Terdapat hal yang unik dalam kejadian bencana tersebut yaitu tidak dapat diprediksi kapan berakhirnya pandemi covid-19. Sejak awal kemunculan kasus pertama pasien positif covid-19 pada bulan februari 2020 di Depok beberapa kasus penularan semakin bertambah hingga pada akhirnya Presiden menetapkan covid-19 sebagai kejadian bencana nasional. Perintah tersebut ditindaklanjuti oleh BNPB selaku lembaga yang bertugas menangani kejadian bencana dengan mengeluarkan status tanggap darurat bencana covid-19 dari tanggal 29 februari hingga $29 \mathrm{Mei}$ 2020 diatur dalam Keputusan Kepala Badan Penanggulangan Bencana Nasional Nomor 13.A Tahun 2020.

Status tanggap darurat covid-19 secara nasional berakhir pada bulan mei 2020 setelah itu pemerintah memberlakukan kebiasaan baru disebut New Normal. Namun status tanggap darurat covid-19 di sejumlah daerah masih berlaku sampai akhir 2020 bahkan sampai tahun 2021. Beberapa daerah tersebut diantaranya tanggap darurat Kabupaten sleman hingga bulan Oktober 2020 (KepGub 66/Kep.KDH/A/2020), D.I 
Yogyakarta hingga bulan Februari 2021 (KepGub 28/kep/2021), Kota Samarinda hingga 31 Maret 2021 (Kep. Walikota 360/449/HK-KS/XII/2020), DKI Jakarta yang merupakan episentrum covid-19 memberlakukan PSBB hingga Februari 2021 (SIARAN PERS: 1887/SPHMS/01/2021). Pada fase tanggap darurat bencana covid-19 yang masih berlaku di sejumlah daerah di Indonesia memberikan gambaran bahwa kasus covid-19 masih berlangsung dengan ditunjukkannya angka pasien positif yang terus meningkat. Data pada 13 Februari 2021 kasus terkonfirmasi Indonesia sejumlah 1.210.703 orang, sembuh 1.016.036 orang dan meninggal 32.936 orang. Sementara kasus harian mengalami peningkatan sebanyak 8.844 kasus dan pasien sembuh sebanyak 11.919 orang (covid19.go.id).

Dari kondisi empiris tersebut tahap manajemen bencana covid-19 yang merupakan kejadian bencana nasional hingga saat ini masih dalam fase tanggap darurat ditunjukkan masih tingginya kasus terkonfirmasi secara nasional dan masih diberlakukannya perpanjangan masa tanggap darurat di beberapa daerah. Disisi lain pemerintah menerapkan kebijakan nasional pelonggaran aktivitas masyarakat dengan slogan new normal dan peraturan tentang pemulihan ekonomi nasional.

New normal berasal dari gagasan WHO sebagai bentuk transisi untuk kembali pada kehidupan normal pasca pandemi. Pemerintah melalui Presiden pada bulan Juni 2020 menyatakan gagasan tersebut diterapkan di Indonesia untuk mendorong kembali aktivitas ekonomi dan sosial dengan memberlakukan protokol kesehatan. setelah berlangsungnya new normal ternyata justru membingungkan masyarakat sehingga pemerintah mengganti dengan slogan adaptasi kebiasaan baru. Pergantian slogan tersebut secara substantif sama karena menggunakan protokol kesehatan dalam kegiatan individu dan organisasional (Mas'udi \& Winanti, 2020).

Sedangkan pada pemulihan ekonomi nasional di masa pandemi Covid-19 pemerintah mengeluarkan Peraturan Presiden Republik Indonesia Nomor 108 Tahun 2020 Tentang Perubahan Atas Peraturan Presiden Nomor 82 Tahun 2020 Tentang Komite Penanganan Corona Virus Disease 2019 (Covid-19) dan Pemulihan Ekonomi Nasional. Dalam pasal 3 disebutkan komite diketuai oleh menko perekonomian dan pasal $4 \mathrm{~A}$ disebutkan ketua pelaksana yaitu menteri BUMN 
sementara BPNB bertugas sebagai pembantu tugas dari ketua pelaksana. Baik slogan new normal dan kebijakan pemulihan ekonomi nasional dalam perspektif manajemen bencana sangatlah tidak kompatible dengan masa tanggap darurat covid-19 yang masih berlangsung. Kedua aspek tersebut menjadi bias dalam penentuan tahapan manajemen bencana.

Dikatakan bias karena pada manajemen bencana sangat jelas disebutkan bahwa tanggap darurat merupakan upaya mengurangi bahaya yang ditimbulkan oleh bencana. Namun pada tahap ini upaya melonggarkan kembali aktivitas sosial dan ekonomi cenderung mengarah pada tahap recovery pasca bencana dimana pada kenyataannya pandemi Covid-19 belum berakhir. Dalam siklus bencana, tahap recovery dilakukan setelah bahaya berhenti permanen termasuk aspek hubungan sosial, modal sosial dan psikologis menjadi baik (Adalbahi,2014). Dari sini muncul bias pada manajemen bencana antara tahap tanggap darurat dengan tahap recovery. Pemerintahan daerah selaku manajer darurat dihadapkan pada sejumlah keputusan untuk merecover biaya bencana termasuk meminimalisir kehilangan korban di wilayah yang dipimpinnya sebagai bagian dari reputasi dengan memberikan perlindungan ekstra pada kejadian bencana yang lebih besar.

Roberts \& Wernstedt (2018) mengemukakan dalam teori prospek, manajer darurat cenderung mengambil resiko pada domain kerugian daripada tindakannya kelak dianggap sebagai keuntungan. Temuan studi teori tersebut terdapat bias pada masyarakat umum bahkan pada domain keahlian profesionalitas. Dalam perilaku administrasi bias pada aspek kognitif tersebut berperan membentuk rutinitas kerja. Berdasarkan teori prospek, tindakan tanggap darurat dengan pemberlakuan PSBB di daerah secara ketat yang telah sesuai dengan tahap tanggap darurat disertai penanganan dari pakar kesehatan menimbulkan bias di masyarakat yakni sektor ekonomi menjadikan penanganan Covid-19 belum optimal. Oleh karena itu diperlukan manajer darurat level lokal yang sesuai keahlian profesional yaitu BPBD (leading sector) dan sektor kesehatan (pelaksana) untuk meningkatkan praktik manajemen dalam meminimalisir penyebaran Covid19.

\section{Inkonsistensi Kebijakan PSBB}

Pernyebaran Covid-19 yang begitu cepat mengharuskan pemerintah membatasi mobilitas masyarakat dengan 
kebijakan Pembatasan Sosial Berskala Besar (PSSB) salah satunya melalui pengendalian penumpang transportasi. Dalam Permenhub No. 18 Tahun 2020 tentang Pengendalian Transportasi dalam Rangka Pencegahan Penyebaran Covid-19 memuat izin operasi transportasi di wilayah PSBB. Moda transportasi yang diperbolehkan beroperasi yaitu sepeda motor online dengan ketentuan menerapkan protokol kesehatan secara ketat. Permenhub tersebut dirasa bertentangan dengan Permenkes No. 9 Tahun 2020 tentang pedoman PSBB dimana layanan ekspedisi barang termasuk angkutan roda dua berbasis aplikasi hanya sebatas mengangkut barang dan bukan mengangkut penumpang. Ketidakseragaman aturan tersebut menunjukkan tidak adanya sinergi yang baik antara kementerian kesehatan dan kementerian perhubungan (Surya,2020). Mulai dilonggarkannya PSBB dilatar belakangi kesejahteraan masyarakat sangat minim karena mobilitas sangat dibatasi terutama dalam memenuhi kebutuhan sehari-hari. Secara bertahap pemerintah melonggarkan PSBB dengan fase sebagai berikut (Vitalio, Turnip \& King, 2020);

1. Fase I (1 Juni 2020). Kegiatan sosial dan ekonomi bisa beroperasi namun dibatasi pada pemenuhan kebutuhan penanganan Covid-19

2. Fase II (8 Juni 2020). Semua sektor ekonomi mulai diperbolehkan tanpa diskrimasi dengan protokol ketat. Sementara kontak fisik belum diperbolehkan

3. Fase III (15 Juni 2020). Evaluasi fase II pembukaan sektor jasa dan ekonomi dengan protokol kesehatan. Aktivias di luar diperbolehkan dengan protokol kesehatan. Evaluasi pembukaan kegiatan sosial masyarakat dibatasi 10 orang

4. $\quad$ Fase IV (6 Juli 2020). Evaluasi sektor ekonomi dan jasa fase III dengan protokol kesehatan. Kegiatan outdoor diperblehkan lebih dari 10 orang. Bepergian dengan pembatasan moda transportasi. Serta kegiatan masyarakat masih tetap dibatasi.

5. Fase V (20 dan 27 juli 2020). Membuka seluruh kegiatan sosial dan ekonomi serta evaluasi fase IV sampai dengan awal agustus dengan 
tetap menerapkan protokol secara ketat hingga ditemukan vaksin.

Pelonggaran PSBB pada periode tersebut dirasa terlalu dini dikarenakan belum memenuhi syarat mutlak tes Covid-19 yaitu pemeriksaan 10 ribu orang per hari atau serta pembatasan mobilitas antar wilayah di Indonesia masih belum berjalan baik. Hingga awal tahun 2021 pandemi Covid-19 belum menunjukkan penuruan membuat kementerian dalam negeri menerbitkan Inmendagri Nomor 3 Tahun 2021 tentang Pemberlakuan Pembatasan Kegiatan Masyarakat (PPKM) Berbasis Mikro dan Pembentukan Posko Penanganan Covid-19 di Tingkat Desa dan Kelurahan. PPKM tersebut menggantikan kebijakan PSBB yang dinilai tidak mampu mengurangi penyebaran Covid-19 dimana terjadi pelonggaran aktifitas masyarakat di sektor ekonomi hingga 50 persen serta menambah pegawai yang bekerja di kantor sebesar 50 persen dari kapasitas ruang perkantoran (cnnindonesia, 2021).

Dibukanya kembali aktifias sosial secara luas di tengah peningkatan kasus covid-19 yang terus bertambah menunjukkan lemahnya pengelolaan bencana yang berdampak pada sektor kesehatan dan ekonomi. Dalam UU penanggulangan bencana 24/2007 belum memuat aspek bencana non-alam. Penanganan bencana non-alam masih diatur pada UU yang terpisah yaitu UU No. 4 Tahun 1984 tentang Wabah Penyakit dan UU No. 6 Tahun 2018 tentang Kekarantinaan Kesehatan. Terpisahnya regulasi penanggulangan bencana non-alam dengan UU penanggulangan bencana menimbulkan perbedaan persepsi dan ketidakjelasan aktor utama dalam penanganan bencana non-alam. Tidak hanya sinergi regulasi, struktur lembaga pemerintahan yang menangani Covid-19 saling reaktif dan bertentangan menyebabkan komando gugus penanganan percepatan Covid-19 menjadi tidak jelas dan tidak efektif dalam menyelesaikan masalah (Smeru,2020).

Situasi di atas mencerminkan minimalnya peran BNPB selaku pemerintah pusat dalam tata kelola bencana dan BPBD selaku pemerintah daerah. Pentingnya peran BNPB dan BPBD dimuat dalam UU penanggulangan bencana pasal 51 (2) yaitu menetapkan status sebuah kejadian bencana. Akan tetapi wewenang tersebut tidak dibarengi dengan pengaturan relasi secara jelas antar lembaga berdasarkan status sebuah bencana. Selain itu tidak ada pembagian wewenang dan tanggung 
jawab antara aktor-aktor baik tingkat pusat dan tingkat daerah saat bencana terjadi. Ketidakselasaran dapat ditemui pada ketidaksiapan sejumlah laboratorium pemeriksaan dan konflik dengan kepala daerah dalam penerapan PSBB. Sebenarnya penanggulangan berdasarkan cakupan wilayah bisa merujuk pada UU Pemerintahan Daerah karena dampaknya bersifat lintas provinsi sehingga kewenangan seharusnya berada di BNPB selaku pemerintah pusat (Smeru.2020).

$$
\text { Dalam UU 23/ } 2014 \text { tentang }
$$

Pemerintah Daerah memuat urusan penanggulangan bencana ke dalam suburusan bidang ketentraman, ketertiban umum serta perlindungan masyarakat. Adapun cakupan dampak yang bersifat lintas provinsi atau negara ditangani oleh pemerintah pusat, cakupan dampak lintas kabupaten/kota ditangani oleh pemerintah provinsi dan dampak yang hanya lokal/setempat ditangani oleh pemerintah kabupaten/kota. Dengan struktur kewenangan yang merujuk pada UU pemerintah daerah maka BPBD selaku pemerintah daerah memiliki peran lebih besar serta memperjelas kebijakan saat kejadian bencana terutama pada sistem komando (Faturahman, 2018b).
Dilema Pandemi: Kesehatan atau Ekonomi ? dan Alternatif Kebijakan

Upaya keluar dari permasalahan krisis kesehatan dan ekonomi secara umum dibagi menjadi dua yaitu kelompok yang pro kesehatan dan kelompok yang pro ekonomi. Sebenarnya dua kutub tersebut saling terkait antara kesehatan dan ekonomi. Wallace (2016) mengatakan bahwa industri kapitalis dari teori Marx lebih cenderung komoditas sebagai produksi bukan lebih kepada kegunaan. Kecenderungan lebih konsumerisme berefek pada objek lainnya meskipun konsekuensinya berbahaya. Industri yang berkaitan dengan agribisnis berkaitan erat dengan organisme/ siklus alam. Jika terjadi exploitasi berlebihan oleh sektor industri karena mengejar keuntungan maksimal dengan input seminimal mungkin turut mendorong berkembangnya bakteri patogenik. Bakteri ini sangat membahayakan manusia karena bakteri patogenik sejatinya berinang pada hewan-hewan liar di hutan. Dengan hilangnya habitat asli seiring berkurangnya luasan hutan menyebabkan pindahnya bakteri tersebut ke habitat manusia. Sementara jika kesehatan manusia terancam atau bermasalah dampaknya akan merembet ke sektor ekonomi yang artinya sektor 
kesehatan dan ekonomi saling berkaitan jika salah satu sektor tersebut bermasalah.

Ekonomi yang dipandang sebagai pasar justru menjadi bumerang pada saat krisis pandemi covid-19 dan lebih mengorbankan masyarakat menengah bawah. Sudut pandang pasar tersebut lebih mengutamakan efisiensi dan maximalisasi keuntungan dari pada kesehatan masyarakat selama pandemi terutama bagi masyarakat rentan seperti biaya pengobatan tidak mungkin ditanggung sendiri masyarakat miskin karena biaya mahal. Hal demikian justru semakin menambah penyebaran virus karena masyarakat yang terdampak tidak bisa mendapat pengobatan. Betapa sulitnya keluar dari permasalahan pandemi ini, Purwanto dan Emilia (2020) menyebutkan pada dasarnya persoalan kesehatan dan ekonomi masyarakat di masa pandemi adalah persoalan politik. Sejumlah kebijakan mulai dari pelonggaran PSBB, new normalpembatasan transportasi, kebijakan lockdown total tergantung kelompok yang menganut paham tersebut. Jika kelompok pro kesehatan maka lebih setuju PSBB dilakukan dengan ketat, bagi mereka yang pro ekonomi tidak setuju PSBB ketat diberlakukan. Dengan melihat permasalah dari aspek politis maka pemecahan masalah dapat ditempuh melalui kebijakan berbasis bukti dalam tahap perumusan kebijakan. Dalam kebijakan berbasis bukti diperlukan masukan dari para ahli lintas kepakaran seperti pakar kesehatan, ekonomi, psikolog, sosiolog dan lainnya bahkan masyarakat yang mampu menjelaskan sesuai bidang keahliannya dapat masuk dalam perumusan kebijakan. Sehingga kebijakan yang dihasilkan berdasarkan temuan-teman atau bukti yang dapat diterapkan saat pandemi berlangsung.

Ketidakjelasan komando darurat bencana menjadi permasalahan utama dalam penanganan bencana pandemi covid-19. Merujuk pada UU pemerintah daerah dapat memperjelas kewenangan tanggap darurat bencana di level lokal namun UU tersebut juga menjadi hambatan dalam percepatan penanganan Covid-19. Penerapan otonomi seluasluasnya dengan kepala daerah sebagai aktor utama legitimasi politik memiliki kebijakan yang berbeda dengan daerah lainnya bahkan sama sekali berbeda dengan kebijakan pemerintah pusat terutama bagi daerah yang masih dianggap zona hijau sehingga relokasi anggaran, sistem mitigasi bencana pandemi Covid-19 belum atau tidak dilaksanakan. Dari sinilah diperlukan 
sistem komando yang jelas dengan menunjuk pemerintah pusat yaitu BNPB serta BPBD di level lokal untuk menentukan tindakan, koordinasi, pembagian wewenang saat tanggap darurat bencana.

BNPB sebagai wadah utama penanggulangan bencana seharusnya memiliki sistem tanggap darurat baik bencana alam dan non-alam (kesehatan). Pada tahap darurat bencana Covid-19 memerlukan fasilitas Rumah Sakit (RS) yang lebih fleksibel. Selama ini penunjukkan RS sebagai rujukan pasien Covid-19 oleh Kementerian Kesehatan berjumlah 20 RS adalah RS vertikal dibawah langsung Kementerian Kesehatan. Di sisi lain, RS vertikal tersebut selalu dijadikan rujukan oleh RS dari berbagai daerah untuk menangani pasien non Covid-19 yang tak kalah kritisnya. Bercampurnya pasien Covid dan non Covid di RS vertikal memperberat kerja dari tenaga medis dan tertundanya layanan bagi pasien non Covid yang memerlukan tindakan segera. Penanganan bencana di masa depan diharapkan turut memperbaiki sistem kesehatan dalam masa krisis dan masa darurat bencana. Oleh karena itu penting melakukan pemetaan dan mengatur pola RS dalam situasi bencana menggunakan sistem teknologi informasi untuk menjangkau daerah yang sulit secara geografis. Hal ini dapat dilakukan dengan menggandeng Perguruan Tinggi (fakultas kedokteran) yang terdapat daerah bencana adalah modal kuat terlaksananya sistem kedaruratan kesehatan.

Selain aspek kesehatan yang perlu diperbaiki dalam darurat bencana, komunikasi publik berupa informasi mengenai Covid-19 berasal dari pemerintah setidaknya tidak terdistrak menjadi informasi yang sangat membingungkan masyarakat. Arus informasi yang sangat cepat di masyarakat tanpa adanya kendali memberikan sikap yang berbeda diberbagai elemen masyarakat seperti muncul rasa takut belebihan dengan menutup praktik dokter, pembatasan layanan kesehatan hingga peningkatan kasus rujukan yang semestinya mampu ditangani fasilitas kesehatan primer. Pada aspek komunikasi ini pemerintah perlu menunjuk aktor utama yang berwenang memberikan informasi secara benar (Purwanto \& Emilia, 2020).

Kemampuan menggandeng pihak akademisi untuk percepatan penanganan pandemi sangat diperlukan karena perguruan tinggi memiliki fleksibilitas dalam penyediaan fasilitas kesehatan serta sumberdaya manusia yang 
mumpuni. Dengan mengoptimalkan karya anak bangsa, geliat ekonomi domestik saat pandemi mampu terangkat. Sarana dan prasarana kesehatan yang disediakan oleh negeri sendiri lebih ekonomis daripada mendatangkannya melalui impor. Tidak hanya berhenti di situ, kerja sama dengan akademisi di Indonesia juga perlu dipermanenkan pasca Covid-19 dengan cara memproteksi agar produkproduk yang dihasilkan dapat terus berjalan dari produksi hingga penggunaan. Pembelajaran dari pandemi ini yaitu terbentuknya kemandirian bangsa dengan memproduksi sendiri sarana dan prasarana saat penanganan Covid-19 dan untuk kepentingan jangka panjang (Rangkuman Dies Natalis FEB UI, 2020).

\section{Penutup}

Manajemen bencana Bencana Covid-19 sesuai kondisi empiris Indonesia masih berada pada tahap tanggap darurat ditunjukkan dengan masih bertambahnya kasus positif serta masih diberlakukannya pembatasan aktifitas masyarakat melalui PSBB/PPKM. Penerapan new normal pada situasi darurat menjadikan bias dalam manajemen bencana dikarenakan tahap darurat dan recovery dilakukan pada saat yang bersamaan pada situasi darurat. Bias pada tahapan manajemen ini menjadikan penanganan Covid-19 menjadi kurang optimal dilihat dari koordinasi antar lembaga. BNPB sebagai pemegang komando utama saat darurat bencana kurang mendapatkan peran sehingga kebijakan dari kementerian lebih mendominasi mengakibatkan kebijakan yang disusun sering bertentangan antara sektor kesehatan dan ekonomi.

Kepentingan sektor kesehatan dan ekonomi di masa pandemi Covid-19 adalah saling berkaitan. Kesehatan menjadi syarat penting agar ekonomi tetap berjalan sebaliknya aktivitas ekonomi tetap bisa berjalan jika kesehatan masyarakat dijadikan prioritas. Perumusan kebijakan berbasis bukti pada masa krisis dengan melibatkan pakar keilmuan secara komprehensif serta didukung masyarakat yang menekuni bidang keahlian tertentu sangatalh penting sebagai pertimbangan dalam mewujudkan sinergi kebijakan.

$$
\text { Belajar dari pengalam saat ini }
$$
diperlukan upaya revisi UU penanggulangan bencana untuk memperkuat posisi BNPB dalam mengkoordinasikan sumberdaya strategis (tidak hanya sumberdaya teknis) khususnya darurat bencana non- 
alam. Penanganan bencana di masa darurat dapat diperkuat dengan merujuk UU pemerintah daerah dengan BPBD sebagai aktor utama koordinasi level kabupaten/kota. Penyatuan koordinasi melalui komando BNPB dan BPBD bertujuan menyelaraskan kebijakankebijakan yang saling bertentangan antar lembaga pemerintahan baik pusat dan daerah pada masa daurat bencana.

\section{DAFTAR PUSTAKA}

Aldalbahi, F., et al. (2014). Actors In Disaster Cycle, Analysis of Six Recovery Plans, and Financial Sources For Post-Disaster Community Recovery. Department of Landscape Architecture \& Urban Planning Texas A\&M University.

Badan Nasional Penanggulangan Bencana. (2020). Jumlah Kejadian Bencana Alam di Indonesia (per 29 Desember 2020). Diakses dari https://databoks.katadata.co.id/data publish/2020/12/30/2929bencana-alam-terjadi-di-indonesiasepanjang-2020\#:. Pada 10 Februari 2020

Burdak, M. (2018). Disaster Management Response Cycle in Context of Structural System and Elements. International Journal of Science and Research Vol. 7(9), 998-1002
Carolina, M. (2018). KelemahanKelemahan Penanggulangan Bencana Alam di Indonesia. Buletin APBN pusat kajian anggaran badan keahlian DPR RI Vol.III Edisi 18 Desember 2018.

CNN Indonesia. (2021). Aturan PPKM Mikro Berlaku 9-22 Februari 2021. Diakses dari https://www.cnnindonesia.com/nas ional/20210208074649-20603452/aturan-ppkm-mikroberlaku-9-22-februari-2021 pada 18 Februari 2021

Dzakwan, M., H., A. (2020). Urgensi pembentukan protokol multibencana dalam pandemi covid-19. CSIS Indonesia.

Faturahman, B. M. (2018a). KONSEPTUALISASI MITIGASI BENCANA MELALUI PERSPEKTIF KEBIJAKAN PUBLIK. PUBLISIA: Jurnal Ilmu Administrasi Publik, 3(2), 122-134.

Faturahman, B. M. (2018b). STRATEGY OF EMERGENCY RESPONSE OF FLOOD AND LANDSLIDE DISASTER IN PACITAN REGENCY. Jurnal Ilmu Administrasi (JIA), XV(2), 133-147.

Ikeda, M. \& Palakhamarn, H. (2020). Economic Damage from Natural 
Hazards and Local Disaster Management Plans in Japan and Thailand. ERIA Discussion Paper Series. No.346

Khan, H. \& Vasilescu, L., G. \& Khan, A. (2008). "Disaster Management CYCLE - a theoretical approach," Management and Marketing Journal, University of Craiova, Faculty of Economics and Business Administration, vol. 6(1), pages 4350 ,

Mas'udi, W. \& Winanti, P.,S. (2020). New normal: Perubahan Sosial Ekonomi dan Politik Akibat Covid-19. Yogyakarta, Gadjah Mada University Press.

Peraturan Presiden Republik Indonesia Nomor 108 Tahun 2020 Tentang Perubahan Atas Peraturan Presiden Nomor 82 Tahun 2020 Tentang Komite Penanganan Corona Virus Disease 2019 (Covid-19) dan Pemulihan Ekonomi Nasional

Purwanto,. E., A \& Emilia, O. (2020). New normal sebagai jalan tengah?: kesehatan vs ekonomi dan alternatif kebijakan dalam pandemi Covid-19. Yogyakarta, UGM Press.

Putera, R., E, Valentina, T., R, \& Rosa, S., A., S. (2020). Implementasi
Kebijakan Penataan Ruang Berbasis Mitigasi Bencana Sebagai Upaya Pengurangan Resiko Bencana di Kota Padang. Publik (Jurnal Ilmu Administrasi) Vol 9 (2), 155-167

Roberts, P., S. \& Wernstedt, K. (2018). Decision Biases and Heuristics Among Emergency Managers: Just Like the Public They Manage For? American Review of Public Administration Vol. 49(3) 292-308

Samekto, C., B., D. \& Nuh, M. (2017). Evaluation of community-based settlement reconstruction program: Case study in post-disaster recovery of 2010 Merapi volcano eruption in Cangkringan district, Sleman regency, Yogyakarta Province. JPAS Vol. 1(3), 64-70

Satuan Tugas Penanganan COVID-19. (2021). Pasien Sembuh Dari COVID19 Semakin Bertambah Menjadi 1.016.036 Orang.diakses dari https://covid19.go.id/berita/pasien -sembuh-dari-covid-19-semakinbertambah-menjadi-1016036-orang pada 16 Februari 2021.

Smeru (2020). Mendorong Revisi UU Penanggulangan Bencana Untuk Membangun Tata Kelola Penanggulangan Bencana Yang 
Adaptif Pembelajaran Dari

Penanganan Pandemi Covid-19 Di

Indonesia. No. 5/Agu/2020

Sumarni, Y. (2020).Pandemi Covid-19:

Tantangan Ekonomi dan Bisnis. AlIntaj, Vol. 6(2), 46-58

Surya, T., A. (2020). Inkonsistensi dan Ketidaktegasan Kebijakan Pemerintah dalam Menangani Pandemi Covid-19. Info Singkat, Vol. XII, No.8/II/Puslit/April/2020.

Pusat Penelitian Badan Keahlian DPR RI.

Undang-undang nomor 23 tahun 2014 tentang Pemerintahan Daerah.

Universitas Indonesia. (2020). Kuliah Umum Bersama Menristek/BRIN: Kekuatan Kerjasama dan Inovasi dalam Mengatasi Pandemi Covid-19. Dies Natalis FEB UI 70 Tahun. Diakses dari

https://www.feb.ui.ac.id/blog/2020 /11/13/dies-natalis-feb-ui-70tahun-kuliah-umum-bersamamenristek-brin-kekuatan-

kerjasama-dan-inovasi-dalammengatasi-pandemi-covid-19/ pada 19 Februari 2020.

Vermonte, P., J. \& Dzakwan, M., H., A.. (2020). Strengthening Disaster Preparedness in Indonesia. Diakses dari

https://csis.or.id/publications/stren gthening-disasterpreparedness-inindonesia pada 12 Januari 2021.

Vitalio, K., Turnip, R.,C.,P. \& King, L. (2020). Peringatan Dini, New Normal di Indonesia Bisa Prematur!. Universitas Sanata Dharma diakses dari

https://usd.ac.id/mahasiswa/bem/f 1l3/Kajian\%20New\%20

Normal\%20SPKS.pdf pada 17 Februari 2021.

Wallace, R. (2016). Big Farms Make Big Flu. New York. MONTHLY REVIEW PRESS

Warfield, C.(2008). The Disaster Management Cycle. Diakses dari http://www.gdrc.org/uem/ disasters/1-dm cycle.html pada 15 Februari 2021 